\title{
RpoE1, an extracytoplasmic function sigma factor, is a repressor of the flagellar system in Brucella melitensis
}

\author{
Jonathan Ferooz, $†$ Julien Lemaire, Marie Delory, Xavier De Bolle \\ and Jean-Jacques Letesson
}

Correspondence

Jean-Jacques Letesson jean-jacques.letesson@fundp.ac. be

Received 20 August 2010

Revised 31 December 2010

Accepted 20 January 2011

\author{
Unité de Recherche en Biologie Moléculaire (URBM), Facultés Universitaires Notre-Dame de la \\ Paix Namur (FUNDP), 61 rue de Bruxelles, B-5000 Namur, Belgium
}

\section{INTRODUCTION}

Brucellae are Gram-negative, intracellular pathogenic bacteria that cause brucellosis in a variety of mammals, including humans. For a long time, they were considered as being unflagellated. However, a sheathed flagellum has recently been discovered in Brucella melitensis and flagellar mutants are found to be impaired for infection in vivo (Ferooz \& Letesson, 2010; Fretin et al., 2005; Zygmunt et al., 2006).

The bacterial flagellum is a complex organelle used for motility and consists of at least three structural elements, the basal body, the hook and the filament (Macnab, 1999). The basal body, working as a motor, is embedded within the cell envelope and is anchored in the cytoplasmic membrane via the MS-ring structure, while the hook and filament, which function as a universal joint and a propeller, respectively, extend outwards from the cells (Minamino et al., 2008).

Sigma and anti-sigma factors play important roles in the regulation of the flagellar genes (Smith \& Hoover, 2009). The genome of $B$. melitensis has revealed the presence of genes encoding six sigma factors $(r p o D, r p o H 1, r p o H 2$, rpoE1, rpoE2 and rpoN) (Delory et al., 2006). The rpoD gene encodes the housekeeping sigma factor, the $r p o H 1$ and

†Present address: GlaxoSmithKline Biologicals, 20 Avenue Fleming, B-1300 Wavre, Belgium.

Abbreviations: ECF, extracytoplasmic function; qRT-PCR, quantitative reverse-transcriptase PCR; TEM, transmission electron microscopy.

A supplementary table listing the genes that contain the $\sigma^{\mathrm{E} 1}$ binding site in their promoter is available with the online version of this paper. $r p o H 2$ genes encode two $\sigma^{32}$ homologues, rpoE1 and rpoE2 encode two extracytoplasmic function (ECF) sigma factors and the rpoN gene encodes a $\sigma^{54}$ homologue. The phenotypic characterizations were done on the five nonessential sigma factor mutants $\Delta r p o H 1, \Delta r p o H 2, \Delta r p o E 1$, $\triangle r p o E 2$ and $\Delta r p o N$ (Delory et al., 2006). Interestingly, at early growth phase in rich liquid medium, $\Delta r p o E 1$ overproduces the flagellar hook protein FlgE, suggesting that the flagellar system synthesis could be downregulated by the ECF sigma factor RpoE1 in B. melitensis (Delory et al., 2006).

In this study, we demonstrate that the ECF sigma factor RpoE1 is a flagellar repressor in B. melitensis and that RpoE1 controls the length of the flagellar filament.

\section{METHODS}

Bacterial strains and culture conditions. All strains and plasmids used in this study are listed in Table 1. Brucella strains used in this study were derived from B. melitensis $16 \mathrm{M} \mathrm{Nal}{ }^{\mathrm{r}}$ (spontaneous nalidixic acid resistant mutant selected from B. melitensis $16 \mathrm{M}$, received from A. Macmillan, Central Veterinary Laboratory, Weybridge, UK). Bacterial growth was measured by reading $\mathrm{OD}_{600}$. Growth curves of B. melitensis $16 \mathrm{M}$ and isogenic mutants were performed on a late-exponential overnight cultures obtained in rich liquid 2 YT medium ( $1 \%$ yeast extract, $1.6 \%$ peptone, $0.5 \% \mathrm{NaCl}$ ). $B$. melitensis $16 \mathrm{M}$ and mutant strains were grown with agitation at $37{ }^{\circ} \mathrm{C}$ in 2YT medium containing appropriate antibiotics from an initial culture, with $\mathrm{OD}_{600} 0.05$. Antibiotics were used at the following final concentrations: $100 \mu \mathrm{g}$ ampicillin $\mathrm{ml}^{-1} ; 20 \mu \mathrm{g}$ chloramphenicol $\mathrm{ml}^{-1} ; 50 \mu \mathrm{g}$ kanamycin $\mathrm{ml}^{-1} ; 25 \mu \mathrm{g}$ nalidixic acid $\mathrm{ml}^{-1}$.

Construction of the pflgE-lacZ reporter. Recombinant DNA techniques were carried out using standard protocols (Ausubel et al., 
Table 1. Bacterial strains and plasmids used in this study

$\mathrm{Nal}^{\mathrm{r}}$, Nalidixic acid-resistant; $\mathrm{Kan}^{\mathrm{r}}$, kanamycin-resistant; $\mathrm{Cm}^{\mathrm{r}}$, chloramphenicol-resistant; Amp ${ }^{\mathrm{r}}$, ampicillin-resistant.

\begin{tabular}{|c|c|c|}
\hline Strain or plasmid & Description & Source \\
\hline \multicolumn{3}{|l|}{ B. melitensis } \\
\hline $16 \mathrm{M} \mathrm{Nal}^{\mathrm{r}}$ & Spontaneous nalidixic acid-resistant strain of B. melitensis $16 \mathrm{M}$ & $\begin{array}{l}\text { Laboratory collection; A. P. } \\
\text { MacMillan, Central } \\
\text { Veterinary Laboratory, } \\
\text { Weybridge, UK }\end{array}$ \\
\hline fliC mutant & B. melitensis $16 \mathrm{M} \Delta$ fliC: : $\mathrm{Kan}^{\mathrm{r}}$ & Ferooz et al. (2011) \\
\hline rpoE1 mutant & B. melitensis $16 \mathrm{M} \Delta r p o E 1:: \operatorname{Kan}^{\mathrm{r}}$ & Delory et al. (2006) \\
\hline rpoE2 mutant & B. melitensis $16 \mathrm{M} \Delta r p o E 2:: \operatorname{Kan}^{\mathrm{r}}$ & Delory et al. (2006) \\
\hline rpoH1 mutant & B. melitensis $16 \mathrm{M} \Delta r p o H 1:: \mathrm{Kan}^{\mathrm{r}}$ & Delory et al. (2006) \\
\hline rpoH2 mutant & B. melitensis $16 \mathrm{M} \Delta r p o H 2:: \mathrm{Kan}^{\mathrm{r}}$ & Delory et al. (2006) \\
\hline rpoN mutant & B. melitensis $16 \mathrm{M} \Delta r p o N:: \mathrm{Kan}^{\mathrm{r}}$ & Delory et al. (2006) \\
\hline \multicolumn{3}{|c|}{ 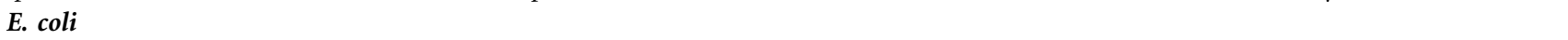 } \\
\hline DH10B & $\begin{array}{l}\mathrm{F}^{-} \text {mcrA } \Delta(\text { mrr hsdRMS morBC }) \phi 80 \text { lacZ } \Delta \mathrm{M} 15 \Delta \text { lacX74 recA1 endA1 } \\
\text { ara } \Delta 139 \Delta(\text { ara leu }) 7697 \text { galU galK } \lambda^{-} \operatorname{rpsL}\left(\mathrm{Str}^{\mathrm{r}}\right) \text { nupG }\end{array}$ & Gibco-BRL \\
\hline S17-1 & thi pro $h s d R$ hsdM $M^{+}$recA RP4-2 (Tc:: Mu-Km::Tn7) & Simon et al. (1983) \\
\hline \multicolumn{3}{|c|}{1} \\
\hline pBBCm-lacZ & Promoterless lac $Z$ vector, $\mathrm{Cm}^{\mathrm{r}}$ & Fretin et al. (2005) \\
\hline pGEM-T Easy & Cloning vector & Promega \\
\hline pGEM-T pflgE & flgE promoter in pGEM-T Easy vector & This study \\
\hline pBBCmpftcR-lacZ & pBBRCm-lacZ vector, promoter $f t c R-l a c Z$ translational reporter, $\mathrm{Cm}^{\mathrm{r}}$ & Léonard et al. (2007) \\
\hline pJF011 & pBBRCm-lacZ vector, promoter fliC-lac $Z$ translational reporter, $\mathrm{Cm}^{\mathrm{r}}$ & Ferooz et al. (2011) \\
\hline pJF012 & pBBRCm-lac $Z$ vector, promoter flgE-lac $Z$ translational reporter, $\mathrm{Cm}^{\mathrm{r}}$ & This study \\
\hline
\end{tabular}

1991). To construct plasmid pJF012, the lacZ coding region with its first $26 \mathrm{nt}$ deleted was cloned into pBBR1MCS as described previously (Fretin et al., 2005). A 589 bp region containing the flgE promoter (including the first $123 \mathrm{bp}$ of the flgE ORF) was amplified from $B$. melitensis $16 \mathrm{M} \mathrm{Nal}^{\mathrm{r}}$ genomic DNA by using the primers in Table 2 containing the $\mathrm{Xba \textrm {I }}$ and BamHI restriction sites. The PCR product was first subcloned into pGEM-T Easy Vector (Promega) and then inserted in-frame upstream of the promoterless lac $Z$ reporter gene into pBBR1MCS to generate the plasmid pJF012.

Detection of FlgE and FliC proteins by Western blot analysis. SDS-PAGE and immunoblotting were performed as described previously (Léonard et al., 2007). Briefly, B. melitensis culture samples were taken at various time points during culture at $37^{\circ} \mathrm{C}$ in $2 \mathrm{YT}$ broth until they reached the appropriate growth phase. Samples of bacterial culture were inactivated for $1 \mathrm{~h}$ at $80{ }^{\circ} \mathrm{C}$ and standardized according to $\mathrm{OD}_{600}$. Total bacterial samples were pelleted and resuspended in SDS sample buffer. The proteins were resolved on a $12 \%$ polyacrylamide gel and transferred to Hybond ECL nitrocellulose membranes (Amersham). The immunodetection of proteins was performed using anti-FliC or anti-FlgE rabbit polyclonal antibodies at dilutions of $1: 3000$ and 1:5000, respectively (Fretin et al., 2005). The detection of primary antibodies was performed using donkey antirabbit (Amersham) horseradish-peroxidase-conjugated secondary antibodies as appropriate, and visualized using the ECL system (Amersham). The measured molecular masses of FlgE and FliC are 41 and $29 \mathrm{kDa}$, respectively. Films were scanned using a Canon CanoScan 3200F and images were analysed using the GIMP 2.6.1

Table 2. Oligonucleotide sequences used in this study

\begin{tabular}{|c|c|c|}
\hline \multirow[t]{2}{*}{ Gene } & \multicolumn{2}{|c|}{ Sequence $\left(5^{\prime} \rightarrow 3^{\prime}\right)$} \\
\hline & Forward primer & Reverse primer \\
\hline \multicolumn{3}{|l|}{ qRT-PCR } \\
\hline fliF (BMEII0151) & ATGAGCTGTTCGACAATATGGG & CTCCTTCGAGCGCGC \\
\hline flgE (BMEII0159) & TTCCGTGAAGAACGCTGC & GAAACGAGATCGCCCGT \\
\hline fliC (BMEII0150) & GTCGATCGTCGCTAATATCAACT & TCGGTCGTCGGGCC \\
\hline flbT (BMEII0163) & AACTTCTGAACGATGCGACAT & AAAGCTGGCGCAGCG \\
\hline flaF (BMEII0162) & AGTTGCGCTACGAAGATGTCA & CAATGGTGCGGTCGAAA \\
\hline \multicolumn{3}{|l|}{ lacZ reporter ${ }^{\star}$} \\
\hline flgE promoter & ATATCTAGAGGGTTCGATCCTATCGATT & ATTGGATCCCGTTTCCGCGCGCTTGTAA \\
\hline
\end{tabular}

${ }^{\star}$ The underlined sequences in the forward and reverse primers are the XbaI and BamHI restriction sites, respectively. 
software. The FlgE and FliC polyclonal antisera cross-reacted with a protein which was used as internal control for equal protein loading.

RNA preparation. Total RNA was extracted from B. melitensis $16 \mathrm{M}$ and the isogenic $\triangle r p o E 1$ mutant (all cultured in triplicate) as follows: $45 \mathrm{ml}$ culture was centrifuged at 3500 r.p.m. (Thermo Electron rotor AB50.10A; $1500 \mathrm{~g}$ ) for $15 \mathrm{~min}$. Bacterial pellets were resuspended in $100 \mu \mathrm{l} 10 \%$ SDS and $20 \mu \mathrm{l}$ proteinase $\mathrm{K}\left(20 \mathrm{mg} \mathrm{ml}^{-1}\right)$ and incubated at $37{ }^{\circ} \mathrm{C}$ with shaking for $1 \mathrm{~h}$. Five millilitres of TRIzol reagent (Invitrogen) was added and suspensions were vigorously shaken. After $10 \mathrm{~min}$ incubation at $65{ }^{\circ} \mathrm{C}, 1 \mathrm{ml}$ chloroform was added to the suspensions and the mixtures were shaken and incubated at room temperature for 5-10 min. Samples were centrifuged at 14000 r.p.m. for $15 \mathrm{~min}$ at $4{ }^{\circ} \mathrm{C}$. Then, an equal volume of $70 \%$ ethanol was added to the aqueous phase and mixed by vortexing. The sample was transferred to the RNA spin cartridge (Invitrogen) and centrifuged at $12000 \mathrm{~g}$ for $15 \mathrm{~s}$ at room temperature. The RNA spin cartridge was washed with buffers I and II supplied with the kit. RNA was eluted from the RNA spin cartridge with $100 \mu \mathrm{l}$ RNase-free water and stored at $-80{ }^{\circ} \mathrm{C}$. The integrity of the RNA and the absence of DNA were checked by gel electrophoresis. RNA quantity was measured using a NanoDrop spectrophotometer (ND-1000, Thermo Fisher Scientific).

Quantitative real-time RT-PCR. RNA samples were treated for DNA digestion with DNase I (Fermentas) and reverse-transcription performed with transcriptor first strand complementary DNA (cDNA) synthesis kit (Roche). cDNA samples were used as template in real-time PCRs. Primers were designed using PrimerExpress 2.0 (Applied Biosystems; sequences are listed in Table 2), PCR products ranged from 80 to $100 \mathrm{bp}$. Real-time PCRs were performed using SYBR Green mix (Applied Biosystems) in 96-well optical reaction plates (Applied Biosystems). Relative quantification using a standard curve method was performed for each set of primers in an Applied Biosystems 7900HT real-time PCR instrument (absolute quantification method). Results for each target mRNA were normalized to BMEI0861 mRNA and averaged as described previously (Uzureau et al., 2010).

Visualization of the flagella by transmission electron microscopy (TEM). Bacteria were grown in rich medium at $37{ }^{\circ} \mathrm{C}$ to $\mathrm{OD}_{600}$ 0.25 as described previously (Ferooz \& Letesson, 2010). The bacteria were centrifuged at 1000 r.p.m. for $20 \mathrm{~min}$ in a Jouan centrifuge, washed in PBS and fixed for $20 \mathrm{~min}$ in $50 \mu \mathrm{l} 4 \%$ paraformaldehyde, $\mathrm{pH}$ 7.3. Bacteria were stored at $4{ }^{\circ} \mathrm{C}$. A carbon Formvar-coated grid was placed on a drop of a solution of $1 \%$ Alcian blue for 5 min, rinsed five times in water and then placed on a drop of bacterial suspension for $10 \mathrm{~min}$. Adherent cells were negatively stained with a $2 \%$ aqueous solution of uranyl acetate for $10 \mathrm{~s}$. Samples were examined with a transmission electron microscope (Technai 10, Philips).

\section{RESULTS}

\section{Production of flagellin in B. melitensis sigma factor mutants}

We firstly analysed the impact of the mutation of sigma factors on the production of flagellin FliC (filament monomers) in B. melitensis. To identify whether the sigma factors RpoN, RpoH1, RpoH2, RpoE1 and RpoE2 are involved in FliC synthesis, we performed a Western blot analysis with the anti-FliC antibody on the five sigma factor mutants. A sample of each mutant and the
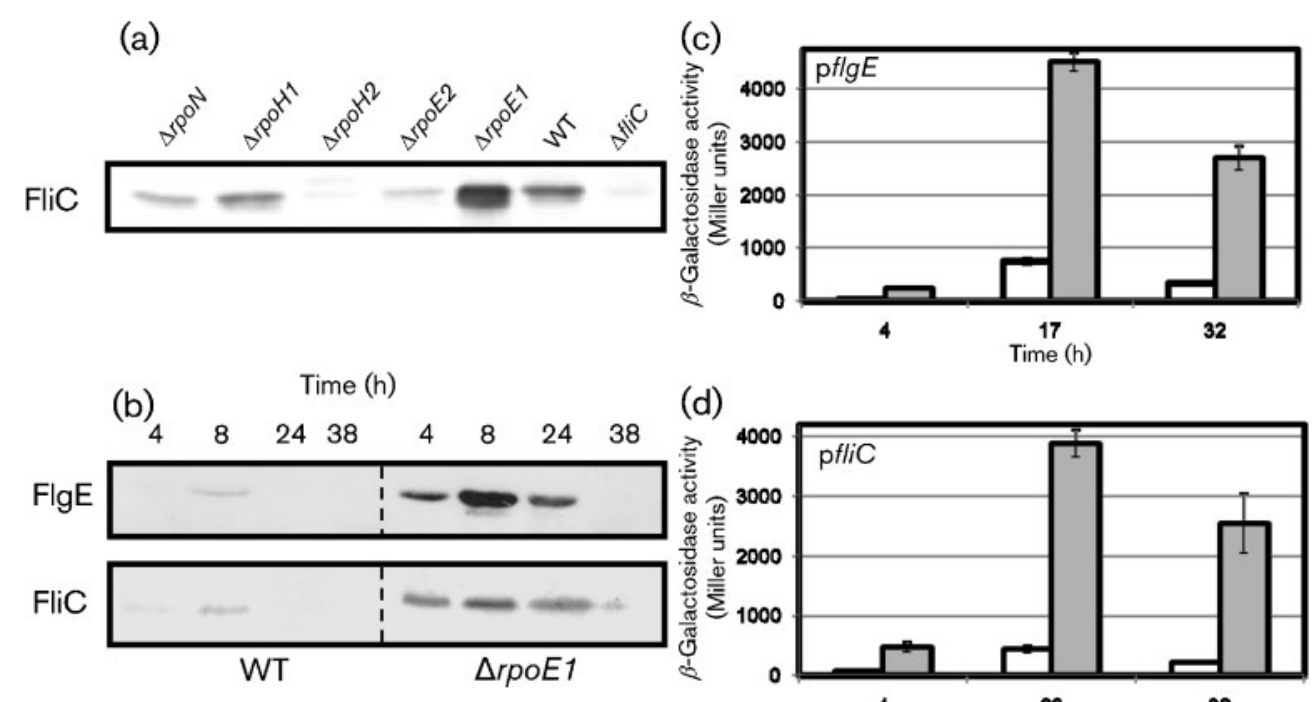

(d)

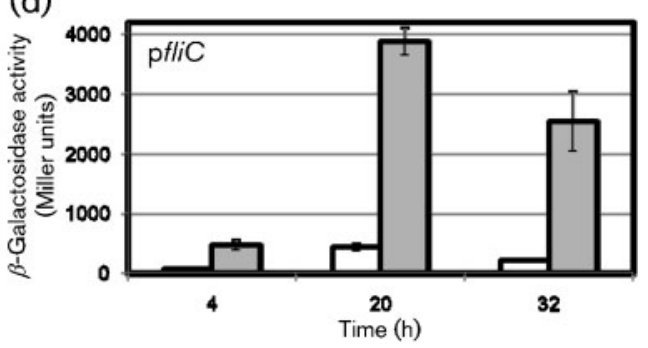

Fig. 1. Western blots of SDS-PAGE protein gels probed with anti-FliC and anti-FlgE polyclonal antisera. (a) Early exponentialphase cultures were harvested from $2 Y T$ growth medium. The $\Delta$ fliC mutant was used as a negative control. Flagellin migrates at an estimated molecular masses of $29 \mathrm{kDa}$. (b) The B. melitensis wild-type strain (WT) and $\Delta r p o E 1$ mutant $(\Delta r p o E 1)$ cultures were harvested after 4, 8, 24 and $38 \mathrm{~h}$ of growth in $2 \mathrm{YT}$ growth medium. FliC and FlgE migrate at estimated molecular masses of 29 and $41 \mathrm{kDa}$, respectively. (c, d) Expression of the $f / g E$ (c) and fliC (d) translational fusions in B. melitensis 16M wild-type (white bars) and $\triangle r p o E 1$ (grey bars) strains. Cells were grown at $37{ }^{\circ} \mathrm{C}$ in $2 \mathrm{YT}$ rich medium and harvested after the indicated

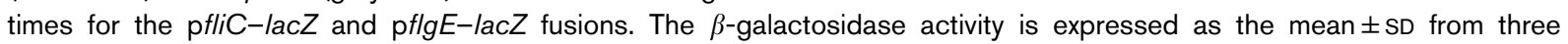
independent experiments. 
B. melitensis wild-type strain were harvested at the early growth phase in rich medium (Fig. 1a). As demonstrated previously, flagellar expression only occurs at the early growth phase in B. melitensis (Fretin et al., 2005). Our results showed that the $\Delta r p o H 2$ mutant did not produce FliC, while the $\Delta r p o E 1$ mutant overproduced it (Fig. 1a) (Delory et al., 2006). Because the $\Delta r p o H 2$ mutant presents a pleiotropic phenotype (Delory et al., 2006) rather than a specific action on the flagellar genes, we did not further characterize the flagellar phenotype of this mutant, and focused our research on the rpoE1 mutant.

\section{Mutation of rpoE1 induces overproduction of the flagellar system}

Interestingly, Western blot analysis showed that FliC is overproduced in the $\triangle r p o E 1$ mutant, even during stationary phase (Fig. 1b). To confirm that the rpoE1 mutation bypasses the flagellar repression, Western blot analysis was performed with the anti-FlgE (hook monomers) and antiFliC antibodies on the samples harvested throughout growth (Fig. 1b). Compared with the wild-type strain, FlgE and FliC are produced in higher amounts and for a longer time in $\triangle r p o E 1$ (Fig. 1b). In parallel, we also tested the activity of the $f l g E$ and fliC promoters in $\Delta r p o E 1$ compared with the wildtype strain along the growth curve by quantification of $\beta$ galactosidase (Fig. $1 \mathrm{c}$ and $\mathrm{d}$, respectively) produced by strains bearing a lac $Z$ fusion to a promoter of interest. Though the $\beta$-galactosidase activity slightly decreased at stationary phase in $\Delta r p o E 1$, the $\beta$-galactosidase activity is still between 7 and 12 times higher than in the wild-type strain, demonstrating that flagellar expression clearly persists later in the rpoE1 mutant compared with the wild-type strain. This also indicated that the rpoE1 mutation affected the promoter activity of $f l g E$ and $f l i C$.

We also tested the effect of the rpoE1 mutation on other flagellar genes using quantitative RT-PCR (qRT-PCR). We quantified the transcript of $f l i F, f l g E, f l i C, f l b T$ and flaF genes in $\triangle r p o E 1$ compared with the wild-type strain (Fig. 2 ). FliF is the monomer of the MS-ring that is the first part assembled in the flagellum structure, while FlbT and FlaF are two flagellin regulators (Ferooz et al., 2011). Expression of all the flagellar genes tested was found to be higher in $\Delta r p o E 1$ compared with the wild-type strain (Fig. 2a).

\section{RpoE1 represses the expression of the flagellar master regulator $\mathrm{ftc} R$}

The results obtained from qRT-PCR analysis showed that all flagellar genes tested were downregulated in the presence of RpoE1 and, since FtcR stimulates the expression of all other flagellar genes, it is likely that the observed repression of other flagellar genes occurs as a result of the repression of $f t c R$ (Léonard et al., 2007). To further evaluate the effect of RpoE1 on $f t c R$, we used the $f t c R-l a c Z$ fusion (Léonard et al., $2007)$ and quantified $\beta$-galactosidase activity in $\Delta r p o E 1$ compared with the wild-type strain. The results of this experiment revealed that the expression of $f t c R$ was reduced in the presence of RpoE1, suggesting that RpoE1 downregulates the expression of flagellar genes by repressing $\mathrm{ftcR}$ expression at the transcriptional level (Fig. 2b).

\section{RpoE1 controls the length of the filament}

We next examined the phenotype of the $\triangle$ rpoE1 mutant using TEM. Samples of the rpoE1 mutant were stained with
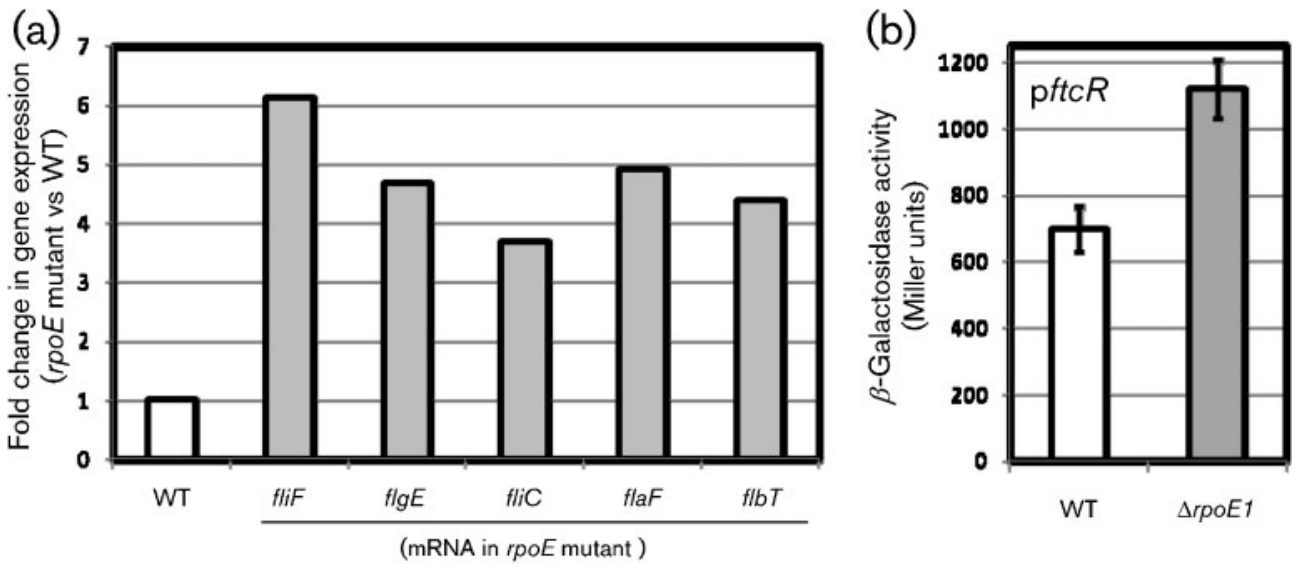

Fig. 2. (a) The amount of $f l i F, f l g E, f l i C, f l a F$ and $f l b T$ transcripts was measured in $\Delta r p o E 1$ and compared with transcripts measured in the wild-type strain (WT). Cells were grown at $37^{\circ} \mathrm{C}$ until the early phase of growth $\left(\mathrm{OD}_{600} 0.2\right)$. The fold change in gene expression in the rpoE mutant is compared with the gene expression in the $B$. melitensis wild-type strain. The level of expression of the gene of interest in the wild-type was set up at 1 . The figure represents average results from three experiments. (b) Expression of the $\mathrm{ftc} R$ translational fusion in $B$. melitensis $16 \mathrm{M}$ wild-type and $\Delta r p o E 1$ strains. Cells were grown at $37^{\circ} \mathrm{C}$ in 2YT rich medium and harvested after $8 \mathrm{~h}$ of growth. The $\beta$-galactosidase activity is expressed as the mean \pm SD from three independent experiments. 

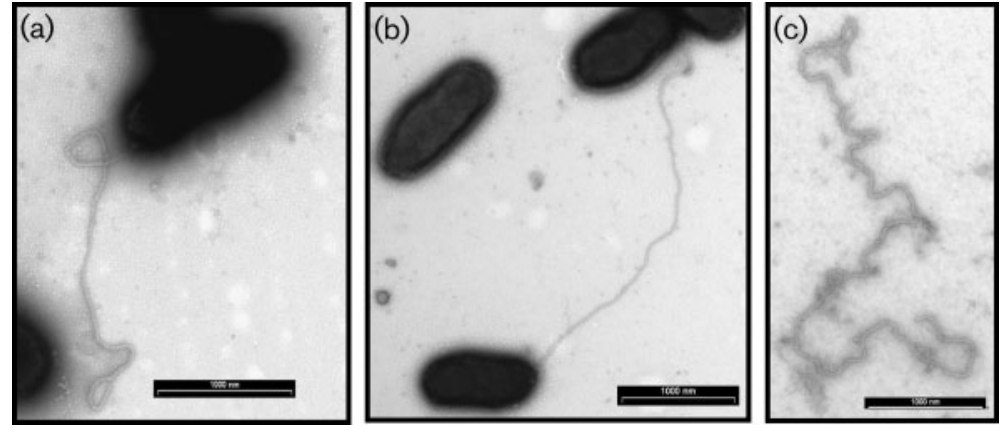

Fig. 3. Negative-staining TEM images of the sheathed polar flagellum from $B$. melitensis wild-type strain (a) and $\Delta r p o E 1$ (b) stained with uranyl acetate $2 \%$. (c) Image of a flagellum from the $r p o E$ mutant. These images are representative of the population observed. Bars, $1 \mu \mathrm{m}$.

$2 \%$ uranyl acetate and examined at different time points. No obvious differences in cell shape or number of flagella were noted. However, compared with the wild-type strain (Fig. 3a), the filament often seems to be longer in the $\Delta r p o E 1$ mutant (Fig. 3b) and we observed more disconnected free flagella in the medium (Fig. 3c).

\section{DISCUSSION}

It has been recently demonstrated that mutation of the sigma factor rpoE1 in B. melitensis increased the production of FlgE at the early exponential growth phase (Delory et al., 2006). In this work, we demonstrate that mutation of rpoE1 also increases the expression of the fliF, flgE, fliC, flaF and $f l b T$ flagellar genes and that RpoE1-mediated repression probably occurs by inhibiting expression of the flagellar master regulator $f t c R$.

In B. melitensis, the promoter activity of the master regulator $f t c R$ is higher in $\triangle r p o E 1$ compared with the wildtype, suggesting that RpoE1 acts upstream of $f t c R$. In Pseudomonas aeruginosa, the flagellar master regulator FleQ controls the flagellum biosynthesis (Arora et al., 1997). In this bacterium, the alternative sigma factor AlgT upregulates the expression of the fleQ transcriptional repressor ArmZ leading to the repression of flagellar expression (Garrett et al., 1999; Tart et al., 2005, 2006). Similar to $P$. aeruginosa, an intermediate RpoE1-dependent regulator could inhibit the expression of $f t c R$ in B. melitensis.

The homologue of B. melitensis RpoE1 in Bradyrhizobium japonicum genome is $\sigma^{\mathrm{EcfG}}$ (Gourion et al., 2009). By analysing the whole genome of B. melitensis with the $\sigma^{\mathrm{EcfG}}$ consensus sequence from Bradyrhizobium japonicum, we have detected 46 genes potentially regulated by RpoE1 based on the DNA pattern search program RSAT (ThomasChollier et al., 2008; Turatsinze et al., 2008) (Supplementary Table S1, available with the online version of this paper). Among them, the presence of rpoE1 suggests an autoregulation, as described in Escherichia coli and other bacteria (Rhodius et al., 2006). In Caulobacter crescentus, Sinorhizobium meliloti, Rhizobium etli and Bradyrhizobium japonicum, the rpoE1 homologues (sigT, rpoE2, rpoE4 and ecfG, respectively) are positively autoregulated (AlvarezMartinez et al., 2007; Gourion et al., 2009; Martínez-Salazar et al., 2009; Sauviac et al., 2007). Among the potential genes regulated by RpoE1 detected in our in silico analysis, BMEI0372 and BMEII0720 encode a PhyR and an AraC transcriptional regulator, respectively, which could repress the flagellar genes. PhyR is an unusual type of response regulator conserved in alphaproteobacteria and consisting of a receiver domain and an ECF sigma factor-like domain (Francez-Charlot et al., 2009; Gourion et al., 2009). It would be interesting to test whether these candidates are regulated by RpoE1 and repress $f t c R$ or other flagellar genes.

Finally, TEM experiments indicated that the flagellum is longer in $\triangle r p o E 1$ than the wild-type strain. The increased length of the filament could be a consequence of the overexpression of flagellar genes. In Campylobacter jejuni and Vibrio cholerae, mutation of flgM induced an increased flagella length (Correa et al., 2004; Wösten et al., 2010). In C. jejuni this increase was correlated with a higher flagellin expression at $42{ }^{\circ} \mathrm{C}$ (Wösten et al., 2010). As soon as the hook-basal body structure is completed, FlgM is secreted through this structure into the environment, releasing FliA and enabling activation of late genes encoding the flagellin to allow the formation of the filament. No FlgM homologue is present in the genome of Brucella; however, the FlaF and FlbT regulators are involved in flagellin synthesis and are also overexpressed in $\Delta r p o E 1$. Despite the presence of a sheath surrounding the flagellum, FlaF and FlbT could also be secreted by the filament and could have a similar effect on flagellar length in B. melitensis. The sheath does not impede secretion by the flagellum, since $\mathrm{FlgM}$ is secreted by the sheathed flagellum of $V$. cholerae (Correa et al., 2004).

In conclusion, this work demonstrates that the ECF sigma factor RpoE1 is a flagellar repressor in B. melitensis and could control the length of the filament. The analysis of the genome of $B$. melitensis with a putative rpoE1 binding motif highlighted several target regulators potentially involved in flagellar repression. Conservation of the genomic organization of the rpoE1 regulon could infer a similar flagellar regulation in other alphaproteobacteria.

\section{ACKNOWLEGMENTS}

We thank Dr Valérie Haine for her critical and careful reading of this manuscript and helpful discussion. We are grateful to Drs Sushila 
Sousa and Bettina Battisti for the helpful manuscript revision. We acknowledge the Service Interfacultaire de Microscopie Electronique of the University of Namur for its expertise in TEM. This work was supported by grants to J. F. from the Fonds Adrien Bauchau and the Fonds National de la Recherche Scientifique. J. F., J. L. and M. D. held a Belgian specialization grant from the Fonds pour la Formation à la Recherche dans l'Industrie et dans l'Agriculture.

\section{REFERENCES}

Alvarez-Martinez, C. E., Lourenço, R. F., Baldini, R. L., Laub, M. T. \& Gomes, S. L. (2007). The ECF sigma factor $\sigma^{\mathrm{T}}$ is involved in osmotic and oxidative stress responses in Caulobacter crescentus. Mol Microbiol 66, 1240-1255.

Arora, S. K., Ritchings, B. W., Almira, E. C., Lory, S. \& Ramphal, R. (1997). A transcriptional activator, FleQ, regulates mucin adhesion and flagellar gene expression in Pseudomonas aeruginosa in a cascade manner. J Bacteriol 179, 5574-5581.

Ausubel, F. M., Brent, R., Kingston, R. E., Moore, D. D., Seidman, J. G., Smith, J. A. \& Struhl, K. (editors) (1991). Current Protocols in Molecular Biology. New York: Wiley.

Correa, N. E., Barker, J. R. \& Klose, K. E. (2004). The Vibrio cholerae FlgM homologue is an anti- $\sigma^{28}$ factor that is secreted through the sheathed polar flagellum. J Bacteriol 186, 4613-4619.

Delory, M., Hallez, R., Letesson, J. J. \& De Bolle, X. (2006). An RpoHlike heat shock sigma factor is involved in stress response and virulence in Brucella melitensis 16M. J Bacteriol 188, 7707-7710.

Ferooz, J. \& Letesson, J. J. (2010). Morphological analysis of the sheathed flagellum of Brucella melitensis. BMC Res Notes 3, 333.

Ferooz, J., Lemaire, J. \& Letesson, J.-J. (2011). Role of FlbT in flagellin production in Brucella melitensis. Microbiology 157, 12531262.

Francez-Charlot, A., Frunzke, J., Reichen, C., Ebneter, J. Z., Gourion, B. $\&$ Vorholt, J. A. (2009). Sigma factor mimicry involved in regulation of general stress response. Proc Natl Acad Sci U S A 106, 3467-3472.

Fretin, D., Fauconnier, A., Köhler, S., Halling, S., Léonard, S., Nijskens, C., Ferooz, J., Lestrate, P., Delrue, R. M. \& other authors (2005). The sheathed flagellum of Brucella melitensis is involved in persistence in a murine model of infection. Cell Microbiol 7, 687-698.

Garrett, E. S., Perlegas, D. \& Wozniak, D. J. (1999). Negative control of flagellum synthesis in Pseudomonas aeruginosa is modulated by the alternative sigma factor AlgT (AlgU). J Bacteriol 181, 7401-7404.

Gourion, B., Sulser, S., Frunzke, J., Francez-Charlot, A., Stiefel, P., Pessi, G., Vorholt, J. A. \& Fischer, H. M. (2009). The PhyR- ${ }^{\text {(EcfG) }}$ signalling cascade is involved in stress response and symbiotic efficiency in Bradyrhizobium japonicum. Mol Microbiol 73, 291-305.

Léonard, S., Ferooz, J., Haine, V., Danese, I., Fretin, D., Tibor, A., de Walque, S., De Bolle, X. \& Letesson, J. J. (2007). FtcR is a new master regulator of the flagellar system of Brucella melitensis $16 \mathrm{M}$ with homologs in Rhizobiaceae. J Bacteriol 189, 131-141.
Macnab, R. M. (1999). The bacterial flagellum: reversible rotary propellor and type III export apparatus. J Bacteriol 181, 7149-7153.

Martínez-Salazar, J. M., Salazar, E., Encarnación, S., Ramirez-Romero, M. A. \& Rivera, J. (2009). Role of the extracytoplasmic function sigma factor RpoE4 in oxidative and osmotic stress responses in Rhizobium etli. J Bacteriol 191, 4122-4132.

Minamino, T., Imada, K. \& Namba, K. (2008). Mechanisms of type III protein export for bacterial flagellar assembly. Mol Biosyst 4, 11051115.

Rhodius, V. A., Suh, W. C., Nonaka, G., West, J. \& Gross, C. A. (2006). Conserved and variable functions of the $\sigma^{\mathrm{E}}$ stress response in related genomes. PLoS Biol 4, e2.

Sauviac, L., Philippe, H., Phok, K. \& Bruand, C. (2007). An extracytoplasmic function sigma factor acts as a general stress response regulator in Sinorhizobium meliloti. J Bacteriol 189, 42044216.

Simon, P., Priefer, U. \& Pühler, A. (1983). A broad host range mobilization system for in vivo genetic engineering: transposon mutagenesis in gram negative bacteria. Biotechnology (N Y) 1, 784791.

Smith, T. G. \& Hoover, T. R. (2009). Deciphering bacterial flagellar gene regulatory networks in the genomic era. Adv Appl Microbiol 67, 257-295.

Tart, A. H., Wolfgang, M. C. \& Wozniak, D. J. (2005). The alternative sigma factor AlgT represses Pseudomonas aeruginosa flagellum biosynthesis by inhibiting expression of fleQ. J Bacteriol 187, 79557962.

Tart, A. H., Blanks, M. J. \& Wozniak, D. J. (2006). The AlgT-dependent transcriptional regulator AmrZ (AlgZ) inhibits flagellum biosynthesis in mucoid, nonmotile Pseudomonas aeruginosa cystic fibrosis isolates. J Bacteriol 188, 6483-6489.

Thomas-Chollier, M., Sand, O., Turatsinze, J. V., Janky, R., Defrance, M., Vervisch, E., Brohée, S. \& van Helden, J. (2008). RSAT: regulatory sequence analysis tools. Nucleic Acids Res 36, W119-W127.

Turatsinze, J. V., Thomas-Chollier, M., Defrance, M. \& van Helden, J. (2008). Using RSAT to scan genome sequences for transcription factor binding sites and cis-regulatory modules. Nat Protoc 3, 15781588.

Uzureau, S., Lemaire, J., Delaive, E., Dieu, M., Gaigneaux, A., Raes, M., De Bolle, X. \& Letesson, J. J. (2010). Global analysis of quorum sensing targets in the intracellular pathogen Brucella melitensis $16 \mathrm{M}$. J Proteome Res 9, 3200-3217.

Wösten, M. M., van Dijk, L., Veenendaal, A. K., de Zoete, M. R., Bleumink-Pluijm, N. M. \& van Putten, J. P. (2010). Temperaturedependent FlgM/FliA complex formation regulates Campylobacter jejuni flagella length. Mol Microbiol 75, 1577-1591.

Zygmunt, M. S., Hagius, S. D., Walker, J. V. \& Elzer, P. H. (2006). Identification of Brucella melitensis $16 \mathrm{M}$ genes required for bacterial survival in the caprine host. Microbes Infect 8, 2849-2854.

Edited by: P. Cornelis 